\title{
Factors Associated with Conservation Participation by Local Communities in Gaurishankar Conservation Area Project, Nepal
}

\author{
Ramesh Paudyal ${ }^{1}\left(\mathbb{D}\right.$, Brijesh Thapa $^{2, *(\mathbb{D})}$, Suman Shree Neupane ${ }^{3}$ and Birendra KC ${ }^{4}(\mathbb{D}$ \\ 1 School of Forest Resources and Conservation, University of Florida, Gainesville, FL 32611, USA; \\ rpaudyal@ufl.edu \\ 2 Department of Tourism, Recreation \& Sport Management, University of Florida, Gainesville, FL 32611, USA \\ 3 Kathmandu Forestry College, Koteshwor, Kathmandu 44600, Nepal; suman@neupane.com.np \\ 4 Department of Hospitality and Tourism Management, University of North Texas, Denton, TX 76203, USA; \\ birendra.kc@unt.edu \\ * Correspondence: bthapa@hhp.ufl.edu; Tel.: +1-352-294-1656
}

Received: 22 July 2018; Accepted: 27 September 2018; Published: 29 September 2018

\begin{abstract}
Information about the factors associated with conservation participation by local communities is important to garner support and involvement within a natural protected area. This research examined how residents' natural resource dependency and other social, economic, and access-related variables predict conservation participation. Data were collected based on a stratified random sampling of households from Gaurishankar Conservation Area Project (GCAP)—a newly designated mountainous protected area in Nepal. Analysis was conducted via an ordered logistic regression model. Higher levels of participation were observed among households that comprised of a larger family size, belonged to a higher caste/ethnicity, resided in higher elevations, and noted frequent visits and interactions with park management staff. However, natural resources dependency (i.e., income and fuelwood fodder) lacked a statistically significant relationship with conservation participation. Similarly, the economic dimension (i.e., land holdings and total livestock unit) was not a significant predictor of participation. Overall, key findings suggest that conservation participation at GCAP needs to be improved with multiple outreach activities, especially to resource-dependent households. More specifically, it is important to ensure equitable access so that locals can participate in programs that provide alternative resource use options, skills development, and trainings for income generation activities.
\end{abstract}

Keywords: decentralization; devolution; participation; dependency; socio-economic; access

\section{Introduction}

Local communities that are in close proximity to parks and protected areas in developing countries are usually highly dependent on natural resources for subsistence living [1-4]. Such resource-dependent communities are typically faced with strict conservation policies and regulations that limit use of natural resources without any alternatives. Furthermore, local communities incur additional costs due to human-wildlife conflict along with lack of access to utilize resources [5-8]. As a result, conservation polices that prioritize limited access and resource utilization from protected areas rarely achieve local community support and involvement [9-11].

Given the challenges of governance and management of natural resources, there has been a shift in conservation policies in numerous developing countries which have led to reforms and/or transfer of management authority to more localized institutions [12-16]. Such localized policy reforms are often operationalized as decentralization or devolution [4,12,17-19]. Essentially, decentralization involves 
transfer of decision-making authority to lower levels of government, whereas devolution involves transfer of rights and responsibilities to local user groups [12].

Since the late 1980s, a form of devolution has been implemented with the establishment of Integrated Conservation and Development Projects (ICDP). The major emphasis of ICDP is to assimilate conservation with participation and local economic development, especially for poor and marginalized communities $[19,20]$. ICDPs are usually facilitated or managed by conservation non-governmental organization, and it delegates power and responsibilities to local communities to encourage their participation in the management of protected areas, along with direct or indirect shared benefits $[10,16,21]$. The success of an ICDP program is assessed in terms of its achievement in conservation as well as its ability to improve economic wellbeing of the local population [22]. However, several ICDP programs globally have been criticized for their failure to achieve either conservation and/or economic development goals. As such, the success rate of ICDP programs are limited with few examples of win-win situations [20,22-27]. Nevertheless, ICDP programs have improved locals' participation in conservation and economic wellbeing in several protected areas $[9,14,22,28,29]$. In addition, decentralization and devolution conservation programs have gained popularity for management of natural resources [30].

A key aspect to a successful decentralization or devolution program is representative participation of all user groups during planning and management of conservation and economic development initiatives, including equitable sharing of benefits [10,19,31-35]. The importance of local participation is crucial as it leads to mobilization for collective action, empowerment, and shared agreement to support new conservation and development initiatives [36]. Nonetheless, socio-political context, underperformance of management agencies, exclusions or lack of opportunities, and obscurity about the role and benefits can negatively affect households' perceptions and participation in conservation projects [37-41]. Further, while local participation is advocated, there are several ways to assess it due to the variation in the level and intensity. Participation has been operationalized based on a typology approach [36,41], while others have used a dichotomy and/or participation in a series of activities measures (i.e., attend meetings, leading meetings, decision making, etc.) $[17,21,31]$.

During the past three decades, Nepal has been a pioneer and leader in the successful adoption and implementation of ICDPs, which has allowed for greater involvement of local communities to participate in conservation programs $[10,14,21,42]$. Nepal has adopted devolution conservation policies via the introduction of various programs, such as community forestry, buffer zones, and establishment of IUCN category VI conservation areas [20,21,26,43,44]. Devolution conservation programs in Nepal have been institutionalized as evidenced with the government's establishment of additional new conservation areas in 2010 (total of five conservation area projects). Among the new entries, Gaurishankar Conservation Area Project (GCAP) is one.

The government of Nepal has transferred the management authority of GCAP to the National Trust for Nature Conservation (NTNC) for 20 years. NTNC is an autonomous and not-for-profit organization established in 1982 via a legislative act. The agency's management of Annapurna Conservation Area Project (ACAP) has been a major successful example of an ICDP program globally $[29,42]$. Likewise, NTNC aims to achieve similar conservation and economic development goals and successes for GCAP. However, several interest groups, such as the Federation of Community Forestry Users Nepal opposed the declaration of GCAP and its management entity. The key arguments relate to locals' access to forests, disintegration of long-established community forestry institutions, lack of management control of local resources, and less priority towards local conservation goals [45,46]. Additionally, several reasons such as bureaucracy, power of constituency, and community sentiments also fueled opposition [46]. A central issue was related to the lack of government's engagement with local communities with regards to decentralized conservation policies, which were only considered during the implementation phase [45,47]. Consequently, various interest groups noted the decision for establishment as undemocratic and non-deliberative [46]. 
The fate of conservation and development initiatives within GCAP depends on both governance and the local communities. Since households may have different needs and perceptions of benefits, the goal to achieve inclusive local participation has been a challenge for NTNC. In addition, voluntary participation by stakeholders is also an issue as they were not properly identified and included during the planning stage. Hence, prior to implementation, several outreach consultations along with negotiations and agreement to revise the management regulations for adequate level of authority to locals in decision making was granted [45]. However, even after several years of implementation, there is a gap in knowledge with regards to its progress, specifically in terms of local support and participation in conservation. As a result, NTNC is limited in information to guide its future management plans and strategies. This research examined the status of, and factors associated with, conservation participation of households $(\mathrm{HH})$ within GCAP. Within this research context, participation refers to HH reported voluntary involvement in conservation in GCAP that includes: attendance in conservation related training or workshop and/or membership in conservation user group programs. This was an adaption from similar studies conducted in Nepal [21,31].

Parks and protected areas create both costs and benefits to local communities due to their existence, which could affect locals' perceptions and conservation participation. For example, crop and livestock losses, conflict with wildlife and management authorities, and opportunity cost of time spent for park-related activities have been identified as major costs $[5-7,15,48]$. Conversely, free or subsidized access of fodder, fuelwood, timber, and other natural resources, earned income, and improved social capital of HH have been noted as major benefits $[8,15,48,49]$. Research has shown that local people are likely to participate in activities when they perceive attainment of benefits as expected [50,51]. Although residents' expectations from a newly established protected area could be beyond the scope and economic viability of the conservation project [52], effective community participation while ensuring fair share of resources through systematic benefit sharing mechanism, and improvement of local economic wellbeing could assist to meet expectations [32]. Direct benefits, such as financial assistance, income generation, and fuelwood/fodder supply received by $\mathrm{HH}$ from conservation areas are related to their participation in conservation programs $[16,21,31]$. However, benefits have not necessarily been accrued by the poor and socially disadvantaged as distributions have largely been controlled by affluent $\mathrm{HH}$ and those from a higher societal class of caste/ethnicity [26,31,53-55]. In this context, caste refers to a form of social class in Hinduism characterized by endogamy and hereditary transmission of occupation, status in a hierarchy, customary social interaction, and exclusion [56,57].

Communities' dependency to natural resources could have significant consequences with preference and decision making, which could add challenges for conservation agencies $[1,58,59]$. Natural resource dependency can also significantly vary within and between communities [26], and also can change over time [60]. In general, $\mathrm{HH}$ with less economic wellbeing or fewer alternative sources of income are more resource-dependent $[1,3,4,60]$. While $\mathrm{HH}$ with large landholdings and livestock units are economically better off, but are still more resource dependent for fuelwood and fodder [26]. The relationship of residents' dependency to natural resources and their participation in conservation programs are mixed. For example, Jumbe and Angelsen [15] found strong positive association between resource dependency and participation from one forest management context, while a strong negative association existed at another site. Overall, the relationship between dependency and conservation participation depends on the relative importance of natural resources on residents' livelihood, social capital, market, and economic environment [15,61]. Residents' dependency to natural resources could serve as an incentive to participate in conservation due to supplementary income and benefits [53], and needs to be maintained for the future [12]. However, if the social context is heterogeneous and $\mathrm{HH}$ do not perceive direct benefits from participation, then higher resource dependency could reduce the incentive to participate [15].

Furthermore, $\mathrm{HH}$ are more resource-dependent if a large proportion of their annual combined income is derived from a conservation area [1]. Thus, the ratio of income obtained to the total $\mathrm{HH}$ income indicates the dependency to natural resources [3,4]. Researchers have also calculated 
fuelwood and fodder dependency in monetary value [58]. However, in several conservation areas, including GCAP, access of fuelwood and fodder from community-managed conservation area forests are free of cost or with subsidized premium. In addition, locally assessed market price of fuelwood and fodder varies among sites. Thus, the calculation of monetary value of fuelwood and fodder is potentially unreliable. Likewise, past studies have also separated farm income and off-farm income with respect to natural resources dependency $[4,62,63]$, but did not account for other income sources accrued from business and related tourism services. To fill this gap in knowledge, this research operationalizes $\mathrm{HH}$ dependency to natural resources via two separate indicators: income dependency and fuelwood-fodder dependency.

In addition to natural resources dependency, various economic, socio-cultural, and access factors have been found to affect management preferences and $\mathrm{HH}$ participation in conservation programs [3, 18,21,31]. Land holding size and total number of livestock indicate the economic status of $\mathrm{HH}$, which could affect participation [21]. Similarly, other variables such as $\mathrm{HH}$ size and caste/ethnicity have been found to have a significant association with participation [18,21,39]. Essentially, $\mathrm{HH}$ that represent a societally defined higher caste hold higher roles of participation in conservation programs [18,31]. Other household-related variables, such as distance to and frequency of visits to park management office, staff visits, and geographic location or elevation (topography) relative to conservation area office also determine levels of participation. For example, HH were more likely to participate due to increased frequency of contacts between park staff and locals [18,21], as well as shorter walking distance/time to reach park management [21]. In addition, $\mathrm{HH}$ of different geographic distribution within the GCAP were found to hold different perceptions about the importance and benefits of conservation [32,64].

Since GCAP was recently established, $\mathrm{HH}$ were likely uncertain about the cost and benefits based on their participation in various programmatic offerings. For a new conservation area project to operate systematically, it is important that residents experience tangible benefits rather than potential costs to participate at the management level. Trainings and workshops related to awareness and income generation activities could assist residents to realize benefits from the implemented programs. This could ultimately facilitate conservation programs to be accepted by public and achieve varying levels of success. However, past research has not included such involvement in operationalization of the participation variable $[18,21,31,40]$. To capture various levels of participation, this research includes attendance in training and workshop as participation. Based on the previous empirical research findings, there is a need to examine participation issues within GCAP, especially since it is a newly designated conservation area. Hence, the purpose of this study was to examine the level of conservation participation among households within GCAP. More specifically, it was to understand how locals' natural resource dependency and other social, economic, and access-related variables predict conservation participation. This research further builds on the academic literature $[15,18,21,31]$, as well as provides new insights given the paucity of research in GCAP. Moreover, the findings can assist the park management authority to assess and accordingly provide outreach initiatives with respect to ensuring equitable access to participation in conservation programs. Two specific research questions were formulated and empirically tested:

1. What is the status of conservation participation among households within GCAP?

2. What factors are associated with conservation participation by households within GCAP?

\section{Methods}

\subsection{Study Area}

The population of interest in this study were residents of GCAP (Figure 1) located within a mountainous region that encompasses $2179 \mathrm{~km}^{2}$ of land, and borders the Sagarmatha National Park (home of Mt. Everest-highest peak in the world) in the east and Langtang National Park in the west. GCAP includes 22 Village Development Committees (VDC) from three districts-Sindhupalchok, 
Dolakha, and Ramechhap. GCAP's headquarter is in Charikot of Dolakha district with three field offices within the conservation area, and operated by 25 employees.

The conservation area has 16 major types of vegetation, and is home to diverse flora and fauna that includes endangered wildlife species, such as red panda and Himalayan musk deer $[65,66]$. As per the most recent census of 2011, a total population of 56,521 from 13,438 households have been documented within this conservation area. In addition, households are heterogeneous with respect to caste/ethnic groups as Tamang (26\%), Sherpa (22\%), and Chhetri (18\%) comprise the majorities. GCAP also offers several destinations for tourists, and is a transit point via a trekking route that links Jiri municipality (a popular tourism destination) of Dolakha district to Sagarmatha (Mt. Everest) National Park.

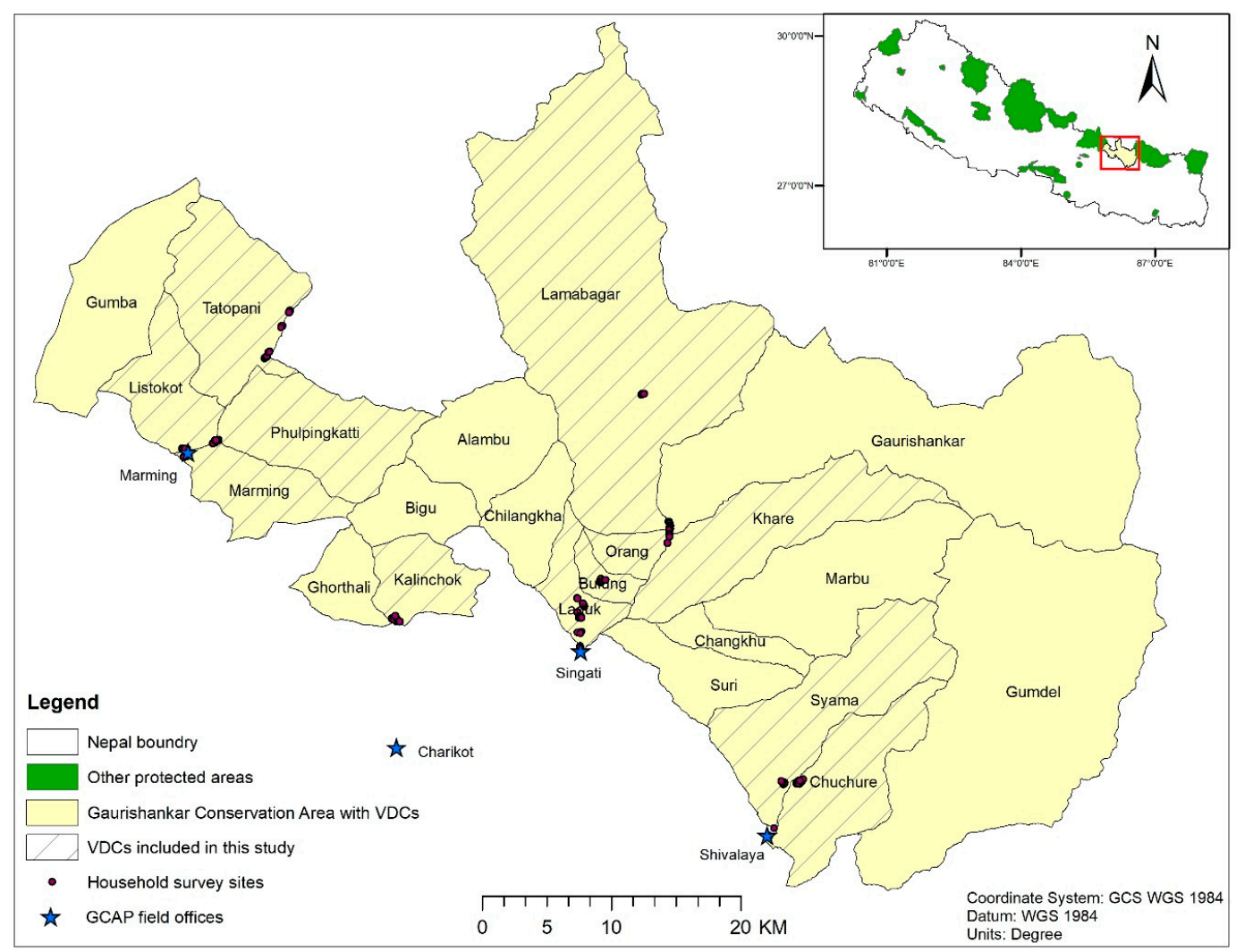

Figure 1. Gaurishankar Conservation Area Project with sampled Village Development Committees and households' locations.

In 2017, 2744 foreign tourists visited GCAP, which is about a $170 \%$ increase in comparison to 2011 [64]. The opportunities for increased tourism development along with new infrastructure and marketing exists, but needs coordination and planning by multiple stakeholders. In addition, the establishment of community-managed programs and realization of benefits by user groups could take several years due to the lack of infrastructure. Collectively, GCAP as a new protected area has challenges, and requires stakeholder participation along with the management authority to ensure park conservation and development opportunities for local communities.

\subsection{Data Collection}

Among the 22 VDCs within the GCAP, this study covered 12 that were accessible by bus. $\mathrm{HH}$ within two hours walking distance from the nearest bus stop were included in the sampling frame. Information about the total number of HH in each VDC was obtained from the GCAP office, and subsequently a minimum target sample was set to 160 . Then, a proportional number of HH from each VDC was selected via a stratified random sampling technique. Data were collected 
between January and March 2017 with a questionnaire survey of HH. A researcher walked to each of the selected $\mathrm{HH}$ and requested the self-identified head of the $\mathrm{HH}$ to participate in the study. If head of the $\mathrm{HH}$ was not available, then the eldest available person (18 years or older) completed the self-administered questionnaire. If the respondent was unable to read the questionnaire (in Nepali language), then questions were narrated by the interviewer and responses were documented (see [21,67]). The questionnaire was initially composed in English, and subsequently translated into the local Nepali language. The authors had the advantage of being proficient in both languages given their origins in Nepal. To further improve clarity of the instrument, it was pilot tested with randomly selected 10 residents from the study area. Collectively, $162 \mathrm{HH}$ were approached and all agreed to respond. Respondents took 15-25 min to complete the questionnaire, and no compensation was provided.

\subsection{Operationalization of Variables}

Participation in conservation activities was the dependent variable. The independent variables tested in the model to examine factors that influence conservation participation were $\mathrm{HH}$ resource dependency, and economic, social, and access-related variables. A descriptive summary of variables is illustrated in Table 1.

Table 1. Descriptive statistics of variables.

\begin{tabular}{|c|c|c|c|c|c|}
\hline Variable & Description & Mean & SD & Min. & Max. \\
\hline Participation & $\begin{array}{l}\text { Household }(\mathrm{HH}) \text { participation roles in Gaurishankar } \\
\text { Conservation Area Project }(\mathrm{GCAP}) .0=\text { none, } 1=\text { attendance, } \\
2=\text { discussion or suggestion, } 3=\text { decision maker }\end{array}$ & 0.42 & 0.81 & 0 & 3 \\
\hline Dependency & HH's dependency levels. & & & & \\
\hline Income dependency $^{\mathrm{a}}$ & Income dependency ratio & 0.36 & 0.40 & 0 & 1 \\
\hline $\begin{array}{l}\text { Fuelwood/fodder } \\
\text { dependency }{ }^{b}\end{array}$ & Fuelwood/fodder dependency ratio & 0.47 & 0.44 & 0 & 1 \\
\hline Economic variables & HHs' economic assets. & & & & \\
\hline Land holdings & Total land owned by the HH (hectare). & 0.46 & 0.59 & 0 & 4.07 \\
\hline Total livestock units & $\begin{array}{l}\text { Cumulative standard unit of livestock from the absolute } \\
\text { number and type possessed by HH. }\end{array}$ & 1.66 & 2.43 & 0 & 14.32 \\
\hline Social variables & HH's family size and caste. & & & & \\
\hline HH size & The number of people that reside within the $\mathrm{HH}$. & 5.49 & 1.93 & 2 & 15 \\
\hline Caste/ethnicity & A binary variable that represents caste/ethnicity of $\mathrm{HH}$. & 0.38 & 0.49 & 0 & 1 \\
\hline Access variables & HH's access-related variables. & & & & \\
\hline HH's visits to GCAP office & A binary variable representing $\mathrm{HH}$ visits to project office & 0.46 & 0.50 & 0 & 1 \\
\hline GCAP staff visits & A binary variable representing project staff's visit to $\mathrm{HH}$ & 0.71 & 0.46 & 0 & 1 \\
\hline Distance to project office & Walking distance (in hours) & 2.17 & 1.89 & 0.02 & 8 \\
\hline Elevation & A categorical variable representing $\mathrm{HH}$ elevation from sea level & 1.64 & 0.68 & 1 & 3 \\
\hline
\end{tabular}

\subsubsection{Participation}

Participation was coded as $0=$ none, $1=$ attendance (if any member of the $\mathrm{HH}$ participated in training and workshops organized by the GCAP or related user group), $2=$ discussion/suggestion (if any member of $\mathrm{HH}$ was a general member of any user group), and $3=$ decision making (if any member of the $\mathrm{HH}$ was an executive member of any user group) [21,31]. It should be noted that user group refers to Conservation Area Management Committee (CAMC) or any sub-committee under CAMC, and membership to user group refers to involvement in CAMC or any sub-committee as a general or executive member. CAMC is a legal institution formed at each VDC as per the Conservation Area Management Regulation. It represents the local communities in each VDC, and acts as an implementing and regulatory agency with respect to conservation and economic development programs. Membership to CAMC is voluntary. Each CAMC includes 15 members, inclusive of one 
chairperson of the VDC, one member from each ward (a lower administrative division of VDC—nine wards in each VDC), and five members nominated by conservation officer representing woman, marginalized and social worker. To ease in the operations of CAMC, there is a legal provision to form related user group sub-committees (e.g., Conservation Forest User Group Sub-Committee, Conservation Farmer Sub-Committee, Tourism Management Sub-Committee, and Conservation Youth Sub-Committee). Before the establishment of conservation area project, locals managed public forests under the Community Forestry Program. Although, Community Forestry Program was displaced by the conservation area, locals have similar opportunities to manage the resources via sub-committees under CAMC within each VDC.

\subsubsection{Resource Dependency}

HH dependency to natural resources was operationalized via two indicators: First, income dependency was operationalized as a ratio of income obtained from jobs/service/labor work and business related to tourism and conservation (e.g., jobs in hotels that serve tourists), non-timber forest products, and agriculture/livestock to the total annual HH income. Second, fuelwood-fodder dependency was measured as a ratio of total amount of fuelwood and fodder obtained from the conservation area forests to the total annual demand of fuelwood and fodder needed for $\mathrm{HH}$ consumption (Table 1).

\subsubsection{Economic Variables}

$\mathrm{HH}$ economic assets were measured with two indicators: land holdings and total livestock units $[18,21,31]$. Land holdings was based on the total land owned by the HH. These data were recorded in the local land measurement units (ropani) and converted to hectares ( 1 hectare $=19.66$ ropani) [71] . Total livestock units were calculated based on the number and type of each livestock owned by the $\mathrm{HH}$ (Table 1). The unit represents a cumulative standard unit of livestock with 1 unit = 1.2 yaks, 1.2 cows, 1.2 buffalo, 1.2 horse, 2 calves, 4 goats, 5 sheep, 5 pigs, or 100 chickens [18,72].

\subsubsection{Social Variables}

Two variables were used to measure $\mathrm{HH}$ social characteristics: family size and caste. Size was the total number of people that resided within the household. Research has shown that $\mathrm{HH}$ with a larger family size were more likely to participate in conservation-related program [18,21]. Caste/ethnicity was a categorical variable that represented a hereditary social class for HH. Past research in a similar context has indicated that $\mathrm{HH}$ from a higher caste were more likely to engage in conservation participation at the decision making level than the lower caste HH [31]. Thus, we coded caste/ethnicity as a binary variable with $1=$ higher caste (Brahmin, Chettri, and Thakuri) and $0=$ others (Tamang, Gurung, Sherpa, Magar, Newar, and Dalit) (Table 1).

\subsubsection{Access Variables}

Based on adaption from the literature $[4,18,21]$, four variables were used to measure $\mathrm{HH}$ access and interactions with GCAP (Table 1). First, HH visits to any project office was coded as 1 (if any of $\mathrm{HH}$ members visited the project offices in last five years), and 0 as otherwise. Second, project staff visits to $\mathrm{HH}$ was coded as 1 (if any of the project staff visited the $\mathrm{HH}$ in last five years), 0 as otherwise. Third, $\mathrm{HH}$ distance to project office was denoted as a continuous variable that represented reported walking distance (in hours) to nearest project office. Fourth, $\mathrm{HH}$ physical location (elevation) from sea level was coded as $1 \leq 1500 \mathrm{~m}, 2=1501-3000 \mathrm{~m}$, and $3>3000 \mathrm{~m}$. The elevation of three field offices within the GCAP are $1700 \mathrm{~m}$ or below. However, at least $50 \%$ of sampled HH were at an elevation of $1700 \mathrm{~m}$ or above. Given the mountainous terrain of GCAP, the condition of trails and monsoon rainy weather typically affects $\mathrm{HH}$ located at higher elevations to reach and contact GCAP staff. Consequently, this limits their participation in conservation activities. Thus, elevation was included as an additional access variable. 


\subsection{Data Analysis}

A descriptive analysis of $\mathrm{HH}$ conservation participation was conducted followed by ordered logistic regression model to identify factors associated with conservation participation. An ordered logistic regression was the appropriate statistical analysis as the dependent variable was a ranking of numbers that represented $\mathrm{HH}$ participation levels in conservation [73]. This model assumes unknown cut points between the categories and equal $\beta$ s for different cut points across the logit equations, also known as proportional odds or parallel regression assumption [73,74]. A Brant test, which compares slope coefficients of the J-1 binary logit regression models was used to verify proportional odds assumption [74]. The analyses were computed in STATA statistical software [75].

\section{Results}

\subsection{Profile of Households}

Among the 22 sampled VDCs from the three districts, six were within range of the Singati field office ( $45 \%$ of sample $\mathrm{HH}$ ), four contained within Marming $(37 \%)$, and two within the Shivalaya field office (18\%). Among the sampled $\mathrm{HH}, 56 \%$ were headed by eldest person with the age range from 18 years to 76 years (average of 39 years). Majority of the respondents were male (67\%), 21\% had no formal or informal education, and $38 \%$ reported 10 years or higher education. Household size ranged $2-15$, with $60 \%$ of $\mathrm{HH}$ with $5-7$ individuals. About $40 \%$ of the $\mathrm{HH}$ belonged to a higher caste/ethnicity (Brahmin, Chettri, and Thakuri), 35\% were Tamang/Gurung/Sherpa, and 17\% were Newar. The average annual demand of $\mathrm{HH}$ fuelwood was $7176 \mathrm{~kg}$, whereas fodder represented $4000 \mathrm{~kg}$. The HH average annual income was reported as US\$2620 (exchange rate US $\$ 1=100$ NRS-March 2017), of which $30 \%$ was earned from income sources related to GCAP. About half of the HH (46\%) visited the management office at least once in the last five years, whereas $71 \%$ of the $\mathrm{HH}$ were visited by the staff at least once during the same period. In addition, $48 \%$ of $\mathrm{HH}$ were within less than $1500 \mathrm{~m}$ in elevation, and $11 \%$ within $3000 \mathrm{~m}$ or higher.

\subsection{Conservation Participation}

Results indicate that almost three-quarter of the sampled HH were not members of any user group, nor did they participate in any training or workshop organized by GCAP, CAMC, or user groups during the past five years (Table 2). About 14\% reported their participation as an attendant of a training or workshop, while $7 \%$ noted their participation as a general member (i.e., discussion or suggestion). Only about $4 \%$ reported their participation as an executive member (i.e., decision maker).

Table 2. Distribution of households' participation levels in GCAP.

\begin{tabular}{lc}
\hline \multicolumn{1}{c}{ Participation Levels } & Percent of Respondents $(n=\mathbf{1 6 2})$. \\
\hline None (no participation) & 74.1 \\
Attendance (participation as an attendant of a training or workshop) & 14.2 \\
Discussion or suggestion (participation as a general member) & 7.4 \\
Decision maker (participation as an executive member) & 4.3 \\
\hline
\end{tabular}

\subsection{Predictors of Conservation Participation}

Results indicated that five out of the ten $\mathrm{HH}$ variables were statistically significant predictors of conservation participation (Table 3). Both economic dimension (i.e., land holdings and total livestock unit) and natural resources dependency (i.e., income and fuelwood-fodder) were not significant predictors of $\mathrm{HH}$ participation in conservation. However, variables within the social dimension (i.e., size and caste/ethnicity) were significant predictors. Further, HH with a larger family size $(\beta=0.41$, $p<0.01)$ and those that represented a socially defined higher caste/ethnicity $(\beta=1.17, p<0.05)$ were more likely to hold higher roles of participation (e.g., decision making) in conservation. An analysis of marginal effects denoted that per person increase in family size was likely to increase participation as 
attendance by $2.4 \%$, discussion/suggestion by $1.9 \%$, and decision making by $1.7 \%$ (Table 4 ). Likewise, $\mathrm{HH}$ from a higher caste/ethnicity were $5.7 \%$ more likely to participate as attendant, $4.6 \%$ as general member, and $4.0 \%$ as executive member.

Table 3. Ordered logistic regression model of households' participation in GCAP.

\begin{tabular}{|c|c|c|}
\hline Independent Variables & Coef. & Std. Err. \\
\hline \multicolumn{3}{|l|}{ Natural resources dependency } \\
\hline Income dependency & 0.73 & 0.52 \\
\hline Fuelwood fodder dependency & 0.50 & 0.49 \\
\hline \multicolumn{3}{|l|}{ Economic variables } \\
\hline Land holding & 0.29 & 0.36 \\
\hline Total livestock unit & -0.01 & 0.09 \\
\hline \multicolumn{3}{|l|}{ Social variables } \\
\hline $\mathrm{HH}$ size & $0.42^{* *}$ & 0.16 \\
\hline Caste/ethnicity & $1.01 *$ & 0.45 \\
\hline \multicolumn{3}{|l|}{ Access variables } \\
\hline HH visits to project management office & $1.22 * *$ & 0.46 \\
\hline HH visits conducted by management staff & $2.55^{* *}$ & 0.87 \\
\hline $\mathrm{HH}$ distance to the project management office & -0.13 & 0.14 \\
\hline HH elevation & $0.99 * *$ & 0.38 \\
\hline \multicolumn{3}{|l|}{ Ancillary parameters } \\
\hline Cut 1 & 8.67 & 1.66 \\
\hline Cut 2 & 9.97 & 1.72 \\
\hline Cut 3 & 11.16 & 1.78 \\
\hline $\mathrm{N}$ & \multicolumn{2}{|c|}{152} \\
\hline LR chi ${ }^{2}$ (p-value) & \multicolumn{2}{|c|}{$47.80(<0.01)$} \\
\hline Pseudo $\mathrm{R}^{2}$ & \multicolumn{2}{|c|}{0.19} \\
\hline Log likelihood & \multicolumn{2}{|c|}{-104.86} \\
\hline
\end{tabular}

Table 4. Marginal effects of the ordered logistic regression model of households' participation in GCAP.

\begin{tabular}{lcccc}
\hline \multirow{2}{*}{ Independent Variables } & \multicolumn{3}{c}{ Participation Level } \\
\cline { 2 - 5 } & None & Attendance & Discussion/Suggestion & Decision-Making \\
\hline HH size & -0.060 & 0.024 & 0.019 & 0.017 \\
Caste/ethnicity & -0.143 & 0.057 & 0.046 & 0.040 \\
HH's visits to project office & -0.172 & 0.068 & 0.056 & 0.048 \\
Project staff visits to HH & -0.360 & 0.143 & 0.117 & 0.100 \\
Elevation & -0.140 & 0.056 & 0.046 & 0.039 \\
\hline
\end{tabular}

Similarly, most variables within the access dimension (i.e., visit to project office, staff visit, and elevation) were significant predictors of participation. $\mathrm{HH}$ that visited project management office $(\beta=1.01, p<0.01)$ as well as those to which staff visited them during the past five years $(\beta=2.64$, $p<0.01$ ) were likely to participate with a higher level of membership. A marginal effect analysis indicated that $\mathrm{HH}$ that visited a project office were $6.8 \%$ more likely to participate as attendant, $5.6 \%$ as general member, and $4.8 \%$ as executive member. Likewise, $\mathrm{HH}$ that were visited by project staff were $14.3 \%$ more likely to participate as attendant, $11.7 \%$ as general member, and $10.0 \%$ as executive member.

$\mathrm{HH}$ elevation was positively associated with participation. Interestingly, $\mathrm{HH}$ located in higher elevations were more likely to participate in conservation $(\beta=0.95, p<0.01)$. The analysis of marginal effects of elevation on participation levels identified that with per unit increase in elevation class ( $\leq 1500 \mathrm{~m}, 1501-3000 \mathrm{~m}$, and $>3000 \mathrm{~m}$ ), HH were $5.6 \%$ more likely to participate as attendants, $4.6 \%$ as general member, and $3.9 \%$ as executive member.

\section{Discussion}

This study examined various factors associated with locals' participation level within a conservation area. Although none of the natural resources dependency and economic dimensions were significant, the social and access-related dimensions were strong predictors of $\mathrm{HH}$ conservation 
participation. Residents with a larger family size and from a higher caste/ethnicity had higher tendencies to participate (including attendance, discussion, and decision-making). This finding was consistent with the literature from similar contexts, where higher caste/ethnicity and affluent $\mathrm{HH}$ were more likely to possess higher levels of participation compared to the poor and lower castes $[18,21,31,55]$. There could be several reasons associated with these findings. First, in our sample, total number of individuals within a $\mathrm{HH}$ ranged from two to 15 persons, with $70 \%$ with a family size of more than five. Extended families with multiple adults have more human resources for the $\mathrm{HH}$ and farm-related activities, which allows for more free time for elder persons to engage in social activities (e.g., participation in conservation committee). Second, $\mathrm{HH}$ with larger family size could perceive less amount of opportunity cost in time attributed for conservation participation. Third, $\mathrm{HH}$ with larger family sizes could have stronger social networks due to extended family or friend relationships, thus improves the chances to be elected or invited to participate in decision making roles of conservation and development programs.

The level of participation is frequently reported to be a major issue as social class affects participation and their role in decision making process [31,39]. Caste/ethnicity system in Nepal is deep-rooted in social strata, with families from higher castes considered as more privileged in terms of social status and education. As a result, they could gain decision-making participation roles and receive more benefits from conservation programs. Unlike the findings in the Kanchenjunga Conservation Area Project [21], GCAP has more heterogeneity in terms of caste/ethnicity. Despite this, our finding shows that $\mathrm{HH}$ from higher caste/ethnicity have more influence on participation roles, which is an added challenge for GCAP to ensure an inclusive participation process for HH that represent the lower castes.

Consistent with the literature, this study also found that increased frequency of $\mathrm{HH}$ visit to management offices along with frequent visits by the staff to $\mathrm{HH}$ were positively associated with participation in conservation [21]. HH with more frequent interactions with the conservation area staff could be more aware about the project and upcoming programs, and hence could foresee benefits that could encourage them to hold higher positions in committees and programs. GCAP has provided various assistance programs, such as toilet construction, homestay and tourists management training, conservation farmer training, conservation guard training, and distribution of improved cooking stoves. $\mathrm{HH}$ that are in frequent contact with the conservation area office could be more informed about such benefits and opportunities. Hence, they were more likely to participate in programs and hold higher positions in conservation committees.

In contrast, residents from higher elevations were more likely to participate in conservation as they usually have fewer alternative options for income generation. Since most large community oriented markets exists in lower elevations, $\mathrm{HH}$ within the vicinity have the advantage of alternative income such as, employment, market access for farm produce, higher market value of goods and services etc. However, $\mathrm{HH}$ in higher elevation lack such alternative opportunities or the options are not easily accessible. Consequently, programs that assist to improve income generation, such as homestay training, non-timber forest products (e.g., Nepalese paperbush, Picrorhiza, and Chiretta) harvesting and processing training, or management authority of nearby public forest for needed fuelwood and fodder resources could be extremely beneficial. Such benefits could likely encourage participation in conservation programs and accordingly reflect their roles.

Resource dependent residents are more likely to support and participate in conservation programs if they foresee benefits $[15,31]$. However, this research found no significant association between $\mathrm{HH}$ natural resource dependency and conservation participation. Findings indicate that there is perhaps lack of incentives for conservation participation among GCAP residents. Moreover, residents may have some preconceived notions that they should compromise their resource dependency equation to promote conservation efforts. Prior to the establishment of GCAP, there was an active community forestry program. Although the community forestry programs claim lack of benefits for the poor and marginalized residents $[26,31,53,54]$, fulfilment of basic needs of forest products (e.g., fuelwood and 
fodder) is considered as one of its strengths [76]. Thus, skepticism with regards to the implementation of GCAP and its expected outcomes (e.g., more focus on conservation rather than on livelihoods) may have played a crucial role for non-participation, especially among residents with high dependency on natural resources. Therefore, GCAP should establish effective communications to educate residents about GCAP's objectives and encourage their participation.

Similarly, consistent with Parker and Thapa [21], we found no significant relationship of land holdings with conservation participation. Research in the context of Nepal's low land protected areas and mid-hill community forestry has shown that landholding size indicates the economic status of $\mathrm{HH}$. Basically, economically affluent $\mathrm{HH}$ with large land sizes are more likely to participate in conservation programs [18,31]. This discrepancy might be due to the large variation in economic value and productivity of land across the geographic regions in Nepal. For instance, Nepal's low land is highly fertile for crop production, and has higher market value for land than in the mountainous terrain. Thus, in high-altitude regions, land holdings may not necessarily indicate economic status of $\mathrm{HH}$.

Likewise, lack of significant relationship existed between total livestock unit and participation. This was consistent with findings from other research conducted at different geographic regions of Nepal $[17,18,21]$. HH with more land and cattle in the mid-hills and higher altitude regions have higher dependency to forests, and spend more time on their farm, and collection of fodder and fuelwood [21,26]. Almost all of our sampled HH had land and livestock as a part of subsistence farming, and did not have significant commercial income from farm-based activities. In addition, land holding size and livestock units ranged from $0-4$ hectares and $0-14$, respectively. This does not constitute much variation in terms of total economic value from land and livestock. Thus, homogeneity of $\mathrm{HH}$ in terms of landholding and livestock could be another reason for lack of significant relationships between the economic dimension and conservation participation.

In this study, the methodological approach and findings offer contributions to the academic literature, especially with respect to the operationalization of both resource dependency and conservation participation. Past studies have measured natural resource dependency as either income dependency [3,4] or a single variable that combines both income and fuelwood-fodder dependency [58]. In this study, income and fuelwood-fodder dependency were separated as two different indicators of natural resource dependency. Additionally, unlike previous research $[4,62,63]$, income from businesses and services related to ecotourism were utilized in the calculation of income dependency. As a result, separate relationships of income dependency and fuelwood/fodder dependency with conservation participation were assessed, although results were inconclusive for both.

With respect to conservation participation, our study expanded this operationalization to include attendance to training or workshops organized by the conservation area. Since GCAP is a newly established conservation area project, where residents are yet to fully experience the costs and benefits, such attendance is important. Particularly, if participation (e.g., attendance in trainings and workshops) is perceived to be beneficial, then this could encourage $\mathrm{HH}$ to take on higher roles (i.e., decision making level) in the future.

\section{Management Implications}

The findings of this study provide management implications for GCAP, and for other newly established protected areas of similar geographic region and context. Overall, $\mathrm{HH}$ participation roles in GCAP has been more influenced by social privileges and selective contacts than forest-based needs. As participation could directly determine acquired benefits [21], our finding indicated that distributions of user rights and benefits were not equal among $\mathrm{HH}$ and communities. These findings clearly signify that non-participation among residents with smaller family size and lower social class act as impediment to the success of GCAP. Thus, it is important to identify the factors that limits $\mathrm{HH}$ participation, and adopt inclusive approaches along with implementation of programs to engage 
all stakeholders. This will likely ensure fair and equitable distribution of benefits to resources-poor $\mathrm{HH}[31]$, and improve collective action for conservation area management.

Our finding suggests that communication with GCAP management authority through outreach programs can positively influence participation. HH who do not visit management entity offices should also be frequented by staff to encourage conservation participation. An opportunity for residents to interact with the staff could assist communities to realize the benefits of the protected area. Thus, GCAP needs to emphasize social mobilization activities to include social capacity trainings and community development projects. Particularly, interactions and dialogues should incorporate activities and skills development related to income generation and poverty alleviation. Governmental fairness on treatment to residents with regard to resources distribution, benefit sharing, input of public and needs would improve locals' social capital, which eventually improves their support to both conservation development program and management authority [77]. Thus, it is important for GCAP staff to gain residents' trust by ensuring their opinions, needs, and preferences are heard, and acted upon by management. Given that there were controversies and oppositions during the establishment of this conservation area, GCAP should better clarify how locals will have decision authority in conservation and development initiatives.

Because of the limited time and funding, this study did not include all the VDCs in GCAP. Since the findings are based on the assessment of accessible VDCs, caution should be taken to generalize these findings to HH located in other remote locations within GCAP. Future research should consider including distant VDCs to better inform participation issues at this conservation area, and validate the findings presented in this study.

\section{Conclusions}

For a conservation area to be successful, it is imperative that resource-dependency of residents is understood, while benefits are permitted to be distributed to ensure their effective participation in programs. This study examined various factors that influence participation in GCAP. Findings offer both academic and practical implications to improve conservation participation among residents in GCAP. Based on the findings, it is important to devise strategies to promote uniform participation from both small-size families and lower social class. It is also central to understand the barriers to participation among households of different social and economic status. Furthermore, residents who are not able to visit project management offices should be approached by staff at their residences. Overall, this study enhances understanding of resource dependency and other social, economic, and access variables in conservation participation, which is useful for GCAP and other similar conservation projects in Nepal and elsewhere.

Author Contributions: R.P. and S.S.N. conceptualized the project and designed the study instrument. S.S.N. conducted the field study and collected data. R.P. and B.T. conceptualized the structure of this paper. R.P. analyzed the data. B.KC provided input for the Discussion and Conclusion Sections. B.T. edited and proofread the paper. All authors contributed to the draft manuscript in various ways.

Funding: This research was partially funded by the National Trust for Nature Conservation, Nepal (Grant no.: H 6660).

Acknowledgments: Authors would like to acknowledge National Trust for Nature Conservation, Nepal for their support of this research. Also, thanks to Abhinandan Khatiwada, Rabin Shrestha, and Dipendra Mehta for their assistance in the field, and Sanam Aksha for assistance with GIS data.

Conflicts of Interest: The authors declare no conflict of interest. The funding sponsors had no role in the design of the study; in the collection, analyses, or interpretation of data; in the writing of the manuscript, and in the decision to publish the results.

\section{References}

1. Vedeld, P.; Angelsen, A.; Sjaastad, E.; Berg, G.K. Counting on the Environment. Forest Incomes and the Rural Poor; The World Bank: Washington, DC, USA, 2004. 
2. Hoehn, S.; Thapa, B. Attitudes and perceptions of indigenous fishermen towards marine resource management in Kuna Yala, Panama. Int. J. Sustain. Dev. World Ecol. 2009, 16, 427-437. [CrossRef]

3. Chandool, C. Households' Resource Use, Conservation Attitude and Perceived Socioeconomic Impact of the Protected Areas Policy in the Nariva Swamp, Trinidad and Tobago. Ph.D. Thesis, University of Florida, Gainesville, FL, USA, 2007.

4. Parker, P.; Thapa, B. Natural resource dependency and decentralized conservation within Kanchenjunga Conservation Area Project, Nepal. Environ. Manag. 2012, 49, 435-444. [CrossRef] [PubMed]

5. Awasthi, B.; Singh, N.B. Status of human-wildlife conflict and assessment of crop damage by wild animals in Gaurishankar Conservation Area, Nepal. J. Inst. Sci. Technol. 2015, 20, 107-111. [CrossRef]

6. Bhattarai, B.R.; Fischer, K. Human-tiger Panthera tigris conflict and its perception in Bardia National Park, Nepal. Oryx 2014, 48, 522-528. [CrossRef]

7. Dhakal, B.; Thapa, B. Buffer Zone Management Issues in Chitwan National Park, Nepal: A Case Study of Kolhuwa Village Development Committee. Parks Int. J. Protect. Areas Conserv. 2015, 21, 63-72. [CrossRef]

8. Allendorf, T.D. Residents' attitudes toward three protected areas in southwestern Nepal. Biodivers. Conserv. 2007, 16, 2087-2102. [CrossRef]

9. Stem, C.J.; Lassoie, J.P.; Lee, D.R.; Deshler, D.D.; Schelhas, J.W. Community participation in ecotourism benefits: The link to conservation practices and perspectives. Soc. Nat. Resour. 2003, 16, 387-413. [CrossRef]

10. Brandon, K.E.; Wells, M. Planning for people and parks: Design dilemmas. World Dev. 1992, 20, 557-570. [CrossRef]

11. Moswete, N.N.; Thapa, B.; Child, B. Attitudes and opinions of local and national public sector stakeholders towards Kgalagadi Transfrontier Park, Botswana. Int. J. Sustain. Dev. World Ecol. 2012, 19, 67-80. [CrossRef]

12. Meinzen-Dick, R.; Knox, A. Collective action, property rights, and devolution of natural resource management: A conceptual framework. In Proceedings of the Workshop on Collective Action, Property Rights, and Devolution of Natural Resource, Puerto Azul, Philippines, 21-25 June 1999; pp. 21-24.

13. Child, B.; Barnes, G. The conceptual evolution and practice of community-based natural resource management in southern Africa: Past, present and future. Environ. Conserv. 2010, 37, 283-295. [CrossRef]

14. Budhathoki, P. Landscape conservation initiatives in Nepal: Opportunities and challenges. In The Protected Landscape Approach: Linking Nature, Culture and Community; Brown, J., Mitchell, N., Beresford, M., Eds.; IUCN_The World Conservation Union: Gland, Switzerland; Cambridge, UK, 2005; pp. 83-92.

15. Jumbe, C.B.; Angelsen, A. Forest dependence and participation in CPR management: Empirical evidence from forest co-management in Malawi. Ecol. Econ. 2007, 62, 661-672. [CrossRef]

16. Khadka, D.; Nepal, S.K. Local responses to participatory conservation in Annapurna Conservation Area, Nepal. Environ. Manag. 2010, 45, 351-362. [CrossRef] [PubMed]

17. Baral, N.; Heinen, J.T. Decentralization and people's participation in conservation: A comparative study from the Western Terai of Nepal. Int. J. Sustain. Dev. World Ecol. 2007, 14, 520-531. [CrossRef]

18. Agrawal, A.; Gupta, K. Decentralization and participation: The governance of common pool resources in Nepal's Terai. World Dev. 2005, 33, 1101-1114. [CrossRef]

19. Diaw, M.C. Elusive meanings: Decentralization, conservation and local democracy. In Governing Africa's Forests in a Globalized World; Routledge: Abingdon-on-Thames, UK, 2009; pp. 80-102.

20. Allendorf, T.D.; Gurung, B. Balancing conservation and development in Nepal's protected area buffer zones. Parks 2016, 22, 69-82.

21. Parker, P.; Thapa, B. Distribution of benefits based on household participation roles in decentralized conservation within Kanchenjunga Conservation Area Project, Nepal. Environ. Dev. Sustain. 2011, 13, 879-899. [CrossRef]

22. Marcus, R.R. Seeing the forest for the trees: Integrated conservation and development projects and local perceptions of conservation in Madagascar. Hum. Ecol. 2001, 29, 381-397. [CrossRef]

23. Heinen, J.T.; Yonzon, P.B. A review of conservation issues and programs in Nepal: From a single species focus toward biodiversity protection. Mt. Res. Dev. 1994, 61-76. [CrossRef]

24. Sandker, M.; Campbell, B.M.; Nzooh, Z.; Sunderland, T.; Amougou, V.; Defo, L.; Sayer, J. Exploring the effectiveness of integrated conservation and development interventions in a Central African forest landscape. Biodivers. Conserv. 2009, 18, 2875-2892. [CrossRef]

25. Oldekop, J.A.; Bebbington, A.J.; Brockington, D.; Preziosi, R.F. Understanding the lessons and limitations of conservation and development. Conserv. Biol. 2010, 24, 461-469. [CrossRef] [PubMed] 
26. Adhikari, B.; Di Falco, S.; Lovett, J.C. Household characteristics and forest dependency: Evidence from common property forest management in Nepal. Ecol. Econ. 2004, 48, 245-257. [CrossRef]

27. Hughes, R.; Flintan, F. Integrating Conservation and Development Experience: A Review and Bibliography of the ICDP Literature; International Institute for Environment and Development: London, UK, 2001.

28. Das, M.; Chatterjee, B. Ecotourism: A panacea or a predicament? Tour. Manag. Persp. 2015, 14, 3-16. [CrossRef]

29. Bajracharya, S.B.; Furley, P.A.; Newton, A.C. Impacts of community-based conservation on local communities in the Annapurna Conservation Area, Nepal. Biodivers. Conserv. 2006, 15, 2765-2786. [CrossRef]

30. Enters, T.; Anderson, J. Rethinking the decentralization and devolution of biodiversity conservation. In Decentralization and Devolution of Forest Management in Asia and the Pacific; Enters, T., Drust, P.B., Victor, M., Eds.; RECOFTC Report No. 18 and RAP Publication 2000/1; RAP Publication: Bangkok, Thailand, 1999; pp. 168-186.

31. Maskey, V.; Gebremedhin, T.G.; Dalton, T.J. Social and cultural determinants of collective management of community forest in Nepal. J. For. Econ. 2006, 11, 261-274. [CrossRef]

32. KC, B.; Paudyal, R.; Neupane, S.S. Residents' perspectives of a newly developed ecotourism project: An assessment of effectiveness through the lens of an importance-performance analysis. Asia Pac. J. Tour. Res. 2018, 23, 560-572. [CrossRef]

33. Kothari, A. Protected areas and people: The future of the past. Parks 2008, 17, 23-34.

34. Andrade, G.S.; Rhodes, J.R. Protected areas and local communities: An inevitable partnership toward successful conservation strategies? Ecol. Soc. 2012, 17. [CrossRef]

35. Bajracharya, S.B.; Gurung, G.B.; Basnet, K. Learning from community participation in conservation area management. J. For. Livelihood 2007, 6, 54-66.

36. Pretty, J.N. Participatory learning for sustainable agriculture. World Dev. 1995, 23, 1247-1263. [CrossRef]

37. Mak, B.K.; Cheung, L.T.; Hui, D.L. Community participation in the decision-making process for sustainable tourism development in rural areas of Hong Kong, China. Sustainability 2017, 9, 1695. [CrossRef]

38. Saufi, A.; O'Brien, D.; Wilkins, H. Inhibitors to host community participation in sustainable tourism development in developing countries. J. Sustain. Tour. 2014, 22, 801-820. [CrossRef]

39. Dahal, S.; Nepal, S.K.; Schuett, M.A. Examining marginalized communities and local conservation institutions: The case of Nepal's Annapurna Conservation Area. Environ. Manag. 2014, 53, 219-230. [CrossRef] [PubMed]

40. Méndez-López, M.E.; García-Frapolli, E.; Ruíz-Mallén, I.; Porter-Bolland, L.; Sánchez-González, M.C.; Reyes-García, V. Who participates in conservation initiatives? Case studies in six rural communities of Mexico. J. Environ. Plan. Manag. 2018, 1-20. [CrossRef]

41. Agarwal, B. Participatory exclusions, community forestry, and gender: An analysis for South Asia and a conceptual framework. World Dev. 2001, 29, 1623-1648. [CrossRef]

42. Nyaupane, G.P.; Thapa, B. Perceptions of environmental impacts of tourism: A case study at ACAP, Nepal. Int. J. Sustain. Dev. World Ecol. 2006, 13, 51-61. [CrossRef]

43. Budhathoki, P. Linking communities with conservation in developing countries: Buffer zone management initiatives in Nepal. Oryx 2004, 38, 334-341. [CrossRef]

44. Heinen, J.T.; Shrestha, S.K. Evolving policies for conservation: An historical profile of the protected area system of Nepal. J. Environ. Plan. Manag. 2006, 49, 41-58. [CrossRef]

45. Paudel, N.S.; Jana, S.; Khatiwada, B. Contestation and citizen-led negotiation around the establishment of protected areas in Nepal Himalaya. J. For. Livelihood 2012, 10, 42-57. [CrossRef]

46. Sunam, R.; Bishwokarma, D.; Darjee, K. Conservation Policy Making in Nepal: Problematising the Politics of Civic Resistance. Conserv. Soc. 2015, 13, 179-188. [CrossRef]

47. Paudel, N.S.; Jana, S.; Rai, J. Protected Areas and Rights Movements: The Inadequacies of Nepal's Participatory Conservation; Discussion Paper Series 10: 3; Forest Action: Kathmandu, Nepal, 2010.

48. Karanth, K.K.; Nepal, S.K. Local residents perception of benefits and losses from protected areas in India and Nepal. Environ. Manag. 2012, 49, 372-386. [CrossRef] [PubMed]

49. Thuy, N.N.; Dwivedi, P.; Rossi, F.; Alavalapati, J.R.R.; Thapa, B. Role of social capital in determining conservation attitude: A case study from Cat Tien National Park, Vietnam. Int. J. Sustain. Dev. World Ecol. 2011, 18, 143-153. [CrossRef] 
50. Lai, P.-H.; Nepal, S.K. Local perspectives of ecotourism development in Tawushan Nature Reserve, Taiwan. Tour. Manag. 2006, 27, 1117-1129. [CrossRef]

51. Moswete, N.; Thapa, B. Factors that influence support for community-based ecotourism in the rural communities adjacent to the Kgalagadi Transfrontier Park, Botswana. J. Ecotour. 2015, 14, 243-263. [CrossRef]

52. Müller-Böker, U.; Kollmair, M. Livelihood strategies and local perceptions of a new nature conservation project in Nepal: The Kanchenjunga Conservation Area Project. Mt. Res. Dev. 2000, 20, 324-331. [CrossRef]

53. Kandel, P.; Chapagain, P.S.; Sharma, L.N.; Vetaas, O.R. Consumption patterns of fuelwood in rural households of Dolakha district, Nepal: Reflections from community forest user groups. Small-Scale For. 2016, 15, 481-495. [CrossRef]

54. Paudel, R.P. Protected Areas, People and Tourism: Political Ecology of Conservation in Nepal. J. For. Livelihood 2016, 14, 13-27.

55. Karki, S.T. Do protected areas and conservation incentives contribute to sustainable livelihoods? A case study of Bardia National Park, Nepal. J. Environ. Manag. 2013, 128, 988-999. [CrossRef] [PubMed]

56. Scott, J.; Marshall, G. A Dictionary of Sociology; Oxford University Press: Oxford, UK, 2009.

57. Winthrop, R.H. Dictionary of Concepts in Cultural Anthropology; Greenwood Press: Westport, CT, USA, 1991.

58. Masozera, M.K.; Alavalapati, J.R. Forest dependency and its implications for protected areas management: A case study from the Nyungwe Forest Reserve, Rwanda. Scand. J. For. Res. 2004, 19, 85-92. [CrossRef]

59. Thapa, S.; Hubacek, K. Drivers of illegal resource extraction: An analysis of Bardia National Park, Nepal. J. Environ. Manag. 2011, 92, 156-164.

60. Cavendish, W. Empirical regularities in the poverty-environment relationship of rural households: Evidence from Zimbabwe. World Dev. 2000, 28, 1979-2003. [CrossRef]

61. Nepal, S.; Spiteri, A. Linking livelihoods and conservation: An examination of local residents' perceived linkages between conservation and livelihood benefits around Nepal's Chitwan National Park. Environ. Manag. 2011, 47, 727-738. [CrossRef] [PubMed]

62. Bhandari, D.; Jianhua, Z. Household Dependency on Buffer Zone Community Forest and its Implication for Management of Chitwan National Park, Nepal. Int. J. Sci. 2017, 6, 68-80. [CrossRef]

63. Parker, P.; Thapa, B.; Jacob, A. Decentralizing conservation and diversifying livelihoods within Kanchenjunga Conservation Area, Nepal. J. Environ. Manag. 2015, 164, 96-103. [CrossRef] [PubMed]

64. Sharma, A.; Paudel, G.; Shrestha, T.K.; Tripathi, S. Ecotourism in Gaurishankar Conservation Area: Source of Income, Satisfaction and Perception of Local People. Int. J. Res. Tour. Hosp. 2018, 4, 8-13.

65. Thapa, A.; Thapa, S.; Poudel, S. Gaurishankar Conservation Area-A Prime Habitat for Red Panda (Ailurus fulgens) in Central Nepal. Initiation 2014, 5, 43-49. [CrossRef]

66. Shresth, B.B.; Meng, X. Spring habitat preference, association and threats of Himalayan musk deer (Moschus leucogaster) in Gaurishankar Conservation Area, Nepal. Int. J. Conserv. Sci. 2014, 5, 535-546.

67. Nyaupane, G.P.; Thapa, B. Evaluation of ecotourism: A comparative assessment in the Annapurna Conservation Area Project, Nepal. J. Ecotour. 2004, 3, 20-45. [CrossRef]

68. Nepal, S.K.; Weber, K.E. Struggle for Existence: Park-People Conflict in the Royal Chitwan National Park, Nepal; Asian Institute of Technology: Bangkok, Thailand, 1993.

69. Balla, M.K.; Chaudhary, S.; Karkee, T.B. Wood energy flows, RRA study in Pokhara, Nepal. In Wood Fuel Flows: Rapid Appraisal in Four Asian Countries; Food and Agriculture Organization of the United Nations: Bangkok, Thailand, 1991; pp. 11-62.

70. Anup, K.C.; Koirala, I.; Adhikari, N. Cost-benefit analysis of a community forest in Nepal. J. Sustain. For. 2015, 34, 199-213.

71. Ha, H. Climate Change Management: Special Topics in the Context of Asia; Business Expert Press: New York, NY, USA, 2018.

72. Scarnecchia, D.L. The animal-unit and animal-unit-equivalent concepts in range science. J. Range Manag. 1985, 38, 346-349. [CrossRef]

73. Fullerton, A.S. A conceptual framework for ordered logistic regression models. Sociol. Methods Res. 2009, 38, 306-347. [CrossRef]

74. Long, J.S.; Freese, J. Regression Models for Categorical Dependent Variables Using Stata; Stata Press: College Station, TX, USA, 2014.

75. StataCorp. Stata Statistical Software: Release 15; StataCorp LLC: College Station, TX, USA, 2017. 
76. KC, B.; Stainback, G.A.; Chhetri, B.B.K. Community users' and experts' perspective on community forestry in Nepal: A SWOT-AHP analysis. For. Trees Livelihoods 2014, 23, 217-231. [CrossRef]

77. Kim, M.; Thapa, B.; Kim, J. Community reactions to tourism development: How does governmental fairness work? J. Environ. Plan. Manag. 2018, 61, 1511-1534. [CrossRef] 